\title{
The Comparison of Penile Doppler Ultrasonography Findings with Serum Lipid Parameters in Hyperlipidemic Patients with Erectile Dysfunction
}

\section{Erektil Disfonksiyonlu Hiperlipidemik Hastalarda Penil Doppler Bulgularının Serum Lipit Parametreleri ile Karşılaştırılması}

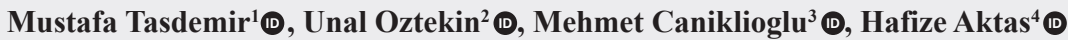 \\ ${ }^{1}$ Department of Radiology, Kayseri Memorial Hospital, Kayseri, Turkey \\ ${ }^{2}$ Department of Urology, Kayseri System Hospital, Kayseri, Turkey \\ ${ }^{3}$ Department of Urology, Yozgat Bozok University Faculty of Medicine, Yozgat, Turkey \\ ${ }^{4}$ Department of Radiology, Ankara Numune Training and Research Hospital, Ankara, Turkey
}

Cite as: Tasdemir M, Oztekin U, Caniklioglu M, Aktas H. The comparison of penile doppler ultrasonography findings with serum lipid parameters in hyperlipidemic patients with erectile dysfunction. Grand J Urol 2021;1(2):49-54.

Submission date: 22 January 2021

Acceptance date: 19 April 2021

Online first: 22 April 2021

Publication date: 20 May 2021

Corresponding Author: Unal Oztekin / Kayseri System Hospital, Department of Urology, Kayseri, Turkey /

dr_unal@hotmail.com ORCID ID: 0000-0001-9568-9442

\section{Abstract}

Objective: The aim of this study is to investigate the effect of hyperlipidemia on the development of erectile dysfunction (ED) in hyperlipidemic patients with ED.

Materials and Methods: Twenty-five patients who applied to the radiology clinic were included in the study. All patients have only hyperlipidemia as a risk factor of ED. The patients were evaluated in terms of ED by using International Index of Erectile Function (IIEF) form. Before and after oral treatment with daily doses of $10 \mathrm{mg}$ atorvastatin, all parameters were measured. Paired t-test was used to compare vascular velocities between lipid profiles and Erectile Function Domain Scores (EFDS) and IIEFs, before and after treatment separately.

Results: Cholesterol levels of $96 \%$ of patients were higher than $200 \mathrm{mg} / \mathrm{dl}$ and $52 \%$ of them had abnormal penile Doppler ultrasonography (PDU) findings. Patients with abnormal PDU findings had lower cholesterol levels than those with normal PDU findings. Significant differences existed between patients with normal and abnormal PDU in the high triglyceride group as for pre-, and post-treatment values . Pre-, and post-treatment EFD and IIEF scores were comparable.

Conclusion: It can be said that a relationship exists between hyperlipidemia and erectile dysfunction. Therefore, lipid profile of a patient admitted with ED may be analyzed routinely

Keywords: hyperlipidemia, statin, erectile dysfunction, penile Doppler

Öz

Amaç: $\mathrm{Bu}$ çalışmanın amacı, erektil disfonksiyonlu (ED) hiperlipidemik hastalarda erektil disfonksiyon gelișiminde hiperlipideminin etkisini araştırmaktır.

Gereçler ve Yöntemler: Bu çalışmaya 25 hasta dahil edildi. Tüm hastalarda ED risk faktörü olarak sadece hiperlipidemi mevcuttu. Hastalar Uluslararası Erektil Fonksiyon Endeksi (IIEF) formu kullanılarak ED açısından değerlendirildi. Atorvastatin $10 \mathrm{mg}$ tedavisinden önce ve sonra tüm parametreler ölçüldü. Lipid profilleri ile Erektil Fonksiyon Alan Skorları (EFDS) ve IIEF'ler arasındaki vasküler hızları tedaviden önce ve sonra ayrı ayrı karşılaştırmak için paired t-testi kullanıldı.

Bulgular: Hastaların \%96'sının kolesterol düzeyleri 200 mg/dl'nin üzerinde ve \% 52'sinde anormal penil Doppler ultrason (PDU) bulguları vardı. Anormal PDU bulguları olan hastalar, normal PDU bulguları olanlara göre daha düşük kolesterol seviyelerine sahipti. Yüksek trigliserid seviyesine sahip olan grupta, anormal ve normal PDU'lu hastaların arasında, tedavi öncesi ve sonrası anlamlı farklılık mevcuttu. Hem EFDS hem de IIEF değerleri tedaviden önceki ile benzerdi.

Sonuç: Hiperlipidemi ile bozulmuş erektil fonksiyon arasında bir ilişki olduğu söylenebilir. Bu nedenle ED ile başvuran hastalarda lipit profili değerlendirilmesi rutin olarak uygulanabilir.

Anahtar kelimeler: hiperlipidemi, statin, erektil disfonksiyon, penil Dopler 


\section{Introduction}

Erectile dysfunction is defined as the failure to create and/ or maintain the necessary rigid erection for a satisfactory sexual intercourse [1].

There is usually a multifactorial etiology. Many psychological, neurological, endocrinological, vascular, pharmacological, traumatic, iatrogenic factors have been described as etiologic factors. Potential risk factors are smoking, advanced age, alcohol addiction, hypertension, hyperlipidemia, diabetes mellitus (DM), depression, vascular diseases, some drugs and some surgical procedures and operations.

Penile erection is a complex physiologic and hemodynamic process that requires an intact arterial blood flow and a venocclusive mechanism in the corpus cavernosum. This process is related to the integration between central and peripheral nervous systems as well as the ratio of the trabecular smooth muscle to the connective tissue in the corpus cavernosum [2].

The most important and most common diagnostic test used in vascular ED is penile color Doppler ultrasonography (US). After an intracavernosal injection of a vasoactive substance (papaverine, prostaglandin E1, etc.), increase in penile artery diameter, blood flow velocity, systolic velocity and end-diastolic velocity can be measured and especially arterial and indirectly venous system can be evaluated in penile color Doppler US.

Penile erection is achieved thanks to adequate arterial distribution. The main cause of arteriolar insufficiency is atherosclerosis but it can also be caused by trauma or congenital anomalies. Atherosclerotic lesions are characterized by smooth muscle proliferation and accumulation of lipid in the vessel wall. Hypercholesterolemia, smoking, DM, exposure to radiation and perineal trauma are risk factors that can be associated with ED [3]. The presence of hypercholesterolemia increases lipid storage in vascular lesions, resulting in atherosclerosis and consequent blockage of blood flow.

Use of high-resolution ultrasonography and quantitative Doppler spectral analysis technique in the evaluation of vasculogenic ED was first described by Lue et al. in 1985 [4]. The cavernous artery exhibits very pronounced gray scale changes after injection of an intracavernosal vasoactive agent. The leading change among these alterations is the increase in arterial diameter. As reported in many studies, the expected increase in the diameter of cavernous arteries varies between 70$100 \%$ [5]. Measurements of maximal systolic velocity (MSV), end- diastolic velocity (EDV), acceleration (A), acceleration time (AT) and resistive index (RI) (RI= MSV-EDV / MSV) have been used to demonstrate the hemodynamic status of the cavernous artery.

Post-injection MSV measurement in arteriogenic ED are the most commonly used parameter in assessing arterial insufficiency. Collins and Lewandowski found average MSV as $26.8 \mathrm{~cm} / \mathrm{sec}$ in patients responding to intracavernous papaverine injection [6]. Most of the studies have accepted MSV values above $30-40 \mathrm{~cm} / \mathrm{sec}$ as normal [7-10].

In cases of venogenic ED excessive venous leakage occurs from corpus cavernosum, In a patient with increased diastolic velocity, venocclusive mechanism is presumably insufficient. The EDV value, which can be considered significant for the assessment of venous leakage, has been reported to be over 5 $\mathrm{cm} / \mathrm{sec}$ in many studies $[8,11]$.

The aim of this study is to compare PDU, IIEF, EFDS results before and after atorvastatin treatment in hyperlipidemic patients with ED.

\section{Material and Methods}

Local ethics committee approval was obtained prior to study. Undersigned informed consent forms were obtained from all patients before the procedure. Twenty-five patients who applied to the 2nd Radiological Clinic of Ankara Numune Training and Research Hospital between April 2005 and August 2005 were included in the study. All patients had only hyperlipidemia as a risk factor of ED. The reference values of total cholesterol, and triglyceride were $112-200 \mathrm{mg} / \mathrm{dl}$ and $50-179 \mathrm{mg} / \mathrm{dl}$, respectively. The patients were questioned regarding the risk factors of ED including history of smoking and alcohol usage urogenital system and/or spinal cord trauma, operation, diabetes, hypertension, atherosclerosis or coronary heart disease, psychiatric disorders, drug usage and hyperlipidemia. Only hyperlipidemia was detected among these risk factors.

Threshold levels of total cholesterol $(200 \leq \mathrm{mg} / \mathrm{dl})$, and triglyceride $(179 \leq \mathrm{mg} / \mathrm{dl})$ were as indicated. The patients whose cholesterol or triglyceride values were higher than the determined levels were evaluated as hyperlipidemic cases.

The patients were also evaluated in terms of erectile function. IIEF form which was validated by Turkish Andrology Association, was used in face to face interview sessions. By this means, EFD and IIEF scores were estimated for each patients. Sum of the scores obtained from all questions in the IIEF form was accepted as the IIEF score, and the total score of the $1,2,3,4,5$ and 15 questions as the EFD score.

After intracavernosal injecting $60 \mathrm{mg}$ papaverine $\mathrm{HCl}$, all patients underwent Doppler US at 0, 5th, 10th, 15th and 30th minutes, and MSV and EDV values were estimated for each patient. MSV of $\geq 30 \mathrm{~cm} / \mathrm{sec}$ and EDV of $\geq 5 \mathrm{~cm} / \mathrm{sec}$ were evaluated as normal threshold values . The patients with MSVs, and EDVs lower than these threshold values were evaluated as having arterial failure and venocclusive deficiency, respectively.

Erectile response was evaluated as below:

Grade 0: No erectile response

Grade 1: Elongation in penile shaft

Grade 2: Mild tumescence

Grade 3: Enough tumescence and erection angle is less than 90 degrees

Grade 4: Enough tumescence and erection angle is greater than 90 degrees (rigid erection)

After oral $10 \mathrm{mg}$ atorvastatin treatment for a month, all parameters were measured again. Paired - $t$ test was used to make comparisons between vascular velocities, lipid profiles, EFDS and IIEF, before and after treatment separately. For statistical analysis IBM SPSS Statistics v25 software is used.

\section{Results}

The mean age of the study participants was $53.7 \pm 10.5$ years, and mean duration of ED twas $37.2 \pm 40$ months. Mean 
Table 1. The comparison of average total cholesterol levels in both normal and abnormal PDU groups, before and after atorvastatin treatment.

\begin{tabular}{l|l|l}
\hline Patients with & Average total cholesterol levels $\mathbf{( m g} / \mathbf{d l})$ \\
\hline & Before atorvastatin treatment & After atorvastatin treatment \\
\hline Normal PDU findings & 249.3 & 166.6 \\
\hline Abnormal PDU findings & 235.8 & 198.3 \\
\hline
\end{tabular}

PDU: Penile Doppler Ultrasound

Table 2. The comparison of average triglyceride levels in both normal and abnormal PDU groups, before and after atorvastatin treatment.

\begin{tabular}{l|l|l}
\hline Patients with & Average triglyceride levels $\mathbf{( m g / \mathbf { d } )}$ \\
\hline & Before atorvastatin treatment & After Atorvastatin \\
\hline Normal PDU findings & 197.3 & 110.1 \\
\hline Abnormal PDU findings & 238.6 & 152.6 \\
\hline
\end{tabular}

PDU: Penile Doppler Ultrasound

Table 3. The comparison of average EFD scores in both normal and abnormal PDU groups, before andafter atorvastatin treatment.

\begin{tabular}{l|l|l}
\hline Patients with & Average EFD scores \\
\hline & Before atorvastatin treatment & After atorvastatin treatment \\
\hline Normal PDU findings & 11.6 & 17.9 \\
\hline Abnormal PDU findings & 11.0 & 17.7 \\
\hline
\end{tabular}

EFDS: Erectile Function Domain Scores; PDU: Penile Doppler Ultrasound

Table 4. The comparison of average IEF scores in both normal and abnormal PDU groups, before andafter atorvastatin treatment.

\begin{tabular}{l|l|l}
\hline Patients with & Average IIEF scores \\
\hline & Before atorvastatin treatment & After atorvastatin treatment \\
\hline Normal PDU findings & 36.4 & 51.4 \\
\hline Abnormal PDU findings & 36.8 & 53 \\
\hline
\end{tabular}

IIEF: International Index of Erectile Function; PDU: Penile Doppler Ultrasound

cholesterol, and triglyceride levels were $242.8 \pm 36.4 \mathrm{mg} / \mathrm{dl}$ and $217.5 \pm 73.3 \mathrm{mg} / \mathrm{dl}$., respectively After treatment these laboratory parameters were 181 and $130 \mathrm{mg} / \mathrm{dl}$, respectively. EFDS was calculated as $11.3 \pm 2.7$ before treatment. After atorvastatin treatment it was $17.8 \pm 2.5$. The average IIEF scores before and after treatment were was 36.6 , and 52 points, respectively. So, we can say that the treatment was clearly effective.

Cholesterol levels of $96 \%$ of the patients were higher than $200 \mathrm{mg} / \mathrm{dl}$ and $52 \%$ of them had abnormal PDU findings. Interestingly, patients with abnormal PDU findings had lower cholesterol levels than those with normal PDU resuls, without significant differences between these patients $(p>0.05)$ (Table 1). Even so, both groups responded to the treatment perfectly.

Ninety-seven percent of the patients had higher triglyceride levels, and as is the case with hypercholesterolemia patients $52 \%$ of the patients had abnormal PDU findings. Before treatment there was a significant difference between the groups $(p<0.05)$. They significantly responded to the treatment (Table 2).

Both EFD and IIEF scores were similar before treatment, in both patient groups with normal and abnormal PDUs. However, atorvastatin treatment improved their erectile functions (Table 3-4).

\section{Discussion}

Etiology of ED still remains unclear. Most of the cases are related to psychological disorders and lipid profile or non-related vascular problems. In rest of the cases, neurogenic problems, smoking, iatrogenic causes, DM, hypertension are the most commonly confronted risk factors [12-14]. It is a fact that ED is more frequent in hyperlipidemic individuals. Some studies have investigated the relation between lipid profile and ED. In a study on 215 patients, Roumegure et al. determined that highdensity lipoprotein (HDL) levels and triglyceride/HDL ratios were important on the development of ED [15]. Kendirci et al. stated that ED was the first signal about endothelial damage in patients with atherogenic risk factors [16]. However, the mechanisms haven't been fully clarified yet.

Rogers JH and Kaiser FE, emphasized the similar changes 
in the vessels of ED patients with coronary artery disease and/ or hyperlipidemia. Similar obstructive lesions starting from the aortic bifurcation to the distal internal pudendal artery were more common. Hyperlipidemia and its resultant macrosvascular atherosclerosis were also more frequent in patients with ED $[17,18]$. Gholami SS et al. determined that a high fat diet causes ED with accompanying neurological and vascular changes in hypercholesterolemic rats. All rats had less nerve content and endothelial cells but higher smooth muscle cells than rats with normal cholesterol levels. In rats treated with colosterol plus phosphate buffered saline electron microscopy showed; denuded andothelial lining of sinusoids covered by multiple platelets, hypermyelination and severe atrophy of axons, a significant decrease in the number and size of nonmyelinated axons, dysregulation of smooth muscle cells with insufficient myofilaments and foamy cytoplasm. [19]. Li R et al. investigated this issue in 14 rats. They found decreased smooth muscle/ collagen ratio, increased fibrosis, increased apoptosis and decreased autophagy in penile tissue of hyperlipidemic rats in as little as six months. As a conclusion they said that hyperlipidemia might decrease erectile function in rats by causing cavernosal fibrosis [20]. Qiu X et al. showed reduced nitric oxide synthase (nNOS) positive nerves, reduced endothelium, and increased cavernous smooth muscle in penile tissues of hyperlipidemic rats. They interpreted the results and associated the mechanism of ED with, decreased number of nNOS-positive nerves and an attenuated endothelium all of which can adversely affect erectile function due to reduced bioavailability of nitric oxide. They also added that the attenuated endothelium causes smooth muscle to lose their contractile ability as the cells become synthetic. According to this study, both structural changes could possibly explain why men with hyperlipidemia, have higher risk of ED [21]. Kobat $\mathrm{M}$ et al. stated that, in men without coronary artery disease, circulating soluble oxidized low-density lipoprotein receptor levels play a role in oxidized LDL-induced damage, which is associated with ED [22].

Both statistical frequency and the above-mentioned literature above make hyperlipidemia important for the ED etiology. Now, we have some relevant histopathologic and laboratory data. Some structural changes that diminish the elasticity of penil micro tissue and structural and/or physiologic deficits of neurons seem responsible for the lack of erection.

We aimed to investigate the correlation between the lipid profile and penile vascular Doppler US findings of ED patients. In our results, we were not able to find any effect of total cholesterol level on ED. However, Saltzman et al. administrated atorvastatin treatment to ED patients, and decrease in lipid levels occurred, the patients improved and showed a good dissese progression [23]. In addition, Wei $\mathrm{M}$ et al. calculated that each $1 \mathrm{mmol} / \mathrm{L}$ increase in total cholesterol levelss was associated with 1.32-fold greater risk of ED. Likewise, every $1 \mathrm{mmol} / \mathrm{L}$ decrease in highdensity lipoprotein levels resulted in a 2.6-fold increase in ED risk [24]. Discordance of our results with the literature may be related with our lower patient counts. It is hard to say "there is no relation between total cholesterol level and ED development" before performing a similar study in a larger group.

In our study triglyceride levels, were significantly higher among the patients with abnormal PDU findings. In the literature, the main trend is accepting risk factors of triglyceride and coronary artery disease (CAD) as predictors of ED. In a study on 3390 male participants, Corona $\mathrm{G}$ et al. found that high triglyceride levels were related with ED [25]. Atahan et al. determined that lipoprotein A and triglyceride levels were higher in both peripheral and cavernosal samples of vasculogenic ED group than in nonvasculogenic ED group. However, there weren't any significant differences in other groups [26]. Kim SC et al. found that lowdensity lipoprotein (LDL) was higher in ED patients, however, triglyceride and cholesterol levels didn't significantly change [27]. Pinnock et al. interpreted high cholesterol and triglyceride levels as the predictor of ED [28]. So, increased triglyceride levels in our study are correlated with the literature data. Also, response of the patients to the atorvastatin treatment, supports that triglyceride and cholesterol levels are related to ED. Both in normal and abnormal PDU groups, there was significant resolution of symptoms after atorvastatin treatment. EFD and IIEF scores were significantly elevated. However, in recent studies long- term statin usage has been held responsible for ED as a result of decreased testosterone levels in hyperlipidemic patients. Corona et al. determined in statin users that testosterone levels were getting lower while follicle stimulating hormone levels were getting higher. They presumed that statin usage might trigger primary hypogonadism and they suggested the clinicians should query the ED patients with low testosterone levels, in terms of statin usage [29]. In contrast, Mondul AM et al. could not determine any negative effect of statin usage on serum sex steroid levels [30]. Further studies are needed to reveal this issue.

\section{Conclusion}

It can be said that a relation exists between hyperlipidemia and erectile dysfunction. When a clinician meets an ED patient, the most confronted etiological factors are psychogenic and vascular disorders, and vascular disorders may be related to hyperlipidemia. Therefore, lipid profile of an ED patient should be routinely assessed at admission. Triglyceride levels appear to be more important than total cholesterol levels. It has been definitely seen that assessment of the ED patients with IIEF forms ensures healthier monitorization of the patients' ED and acquisition of useful quantitative data from them.

Ethics Committee Approval: The study was approved by Ankara Numune Training and Research Hospital Ethical Committee, Cankaya, Ankara, Turkey.

Informed Consent: An informed consent was obtained from all the patients.

Publication: The results of the study were not published in full or in part in form of abstracts.

Peer-review: Externally peer-reviewed.

Authorship Contributions: Any contribution was not made by any individual not listed as an author. Concept - M.T., U.O., M.C., H.A.; Design - M.T., U.O., M.C., H.A.; Supervision M.T., U.O., M.C., H.A.; Resources - M.T., U.O., M.C., H.A.; Materials - M.T., U.O., M.C., H.A.; Data Collection and/ or Processing - M.T., U.O., M.C., H.A.; Analysis and/or Interpretation - M.T., U.O., M.C., H.A.; Literature Search M.T., U.O., M.C., H.A.; Writing Manuscript - M.T., U.O., M.C., 
H.A.; Critical Review - M.T., U.O., M.C., H.A.

Conflict of Interest: The authors declare that they have no conflict of interest.

Financial Disclosure: The authors have declared that they did not receive any financial support for the realization of this study.

\section{References}

[1] NIH Consensus Conference. Impotence. NIH Consensus Development Panel on Impotence. JAMA 1993;270:83-90. https://doi.org/10.1001/jama.270.1.83.

[2] Nehra A, Barrett DM, Moreland RB. Pharmacotherapeutic advances in the treatment of erectile dysfunction. Mayo Clin Proc 1999;74:709-21.

https://doi.org/10.4065/74.7.709.

[3] Breza J, Aboseif SR, Orvis BR, Lue TF, Tanagho EA. Detailed anatomy of penile neurovascular structures: Surgical significance. J Urol 1989;141:437-43. https://doi.org/10.1016/S0022-5347(17)40789-0.

[4] Kessler WO. Nocturnal penile tumescence. Urol Clin North Am 1988;15:81-6. https://doi.org/10.1007/978-3-319-42178-0_3.

[5] Krysiewicz S, Mellinger BC. The role of imaging in the diagnostic evaluation of impotence. Am J Roentgenol 1989; 153:1133-9. https://doi.org/10.2214/ajr.153.6.1133.

[6] Collins JP, Lewandowski BJ. Experience with Intracorporeal Injection of Papaverine and Duplex Ultrasound Scanning for Assessment of Arteriogenic Impotence. Br J Urol 1987;59:84-8. https://doi.org/10.1111/j.1464-410X.1987.tb04587.x.

[7] Benson CB, Aruny JE, Vickers MA. Correlation of duplex sonography with arteriography in patients with erectile dysfunction. Am J Roentgenol 1993;160:71-3. https://doi.org/10.2214/ajr.160.1.8416651.

[8] Bassiouny HS, Levine LA. Penile duplex sonography in the diagnosis of venogenic impotence. J Vasc Surg 1991;13:75-83. https://doi.org/10.1016/0741-5214(91)90014-L.

[9] Schwartz AN, Wang KY, Mack LA, Lowe M, Berger $\mathrm{RE}, \mathrm{Cyr} \mathrm{DR}$, et al. Evaluation of normal erectile function with color flow Doppler sonography. Am J Roentgenol 1989;153:1155-60. https://doi.org/10.2214/ajr.153.6.1155.

[10] Lue TF, Mueller SC, Jow YR, Wang TIS. Functional evaluation of penile arteries with duplex ultrasound in vasodilator-induced erection. Urol Clin North Am 1989;16:799-807.

https://pubmed.ncbi.nlm.nih.gov/2683308/

[11] Meuleman EJH, Bemelmans BLH, Van Asten WNJC, Doesburg WH, Skotnicki SH, Debruyne FMJ. Assessment of penile blood flow by duplex ultrasonography in 44 men with normal erectile potency in different phases of erection. J Urol 1992;147:51-6. https://doi.org/10.1016/S0022-5347(17)37131-8.
[12] McMahon CG, Samali R, Johnson H. Efficacy, safety and patient acceptance of sildenafil citrate as treatment for erectile dysfunction. J Urol 2000;164:1192-6. https://doi.org/10.1016/S0022-5347(05)67139-X.

[13] McMahon CG, Touma K. Predictive value of patient history and correlation of nocturnal penile tumescence, colour duplex Doppler ultrasonography and dynamic cavernosometry and cavernosography in the evaluation of erectile dysfunction. Int J Impot Res 1999;11:47-51. https://doi.org/10.1038/sj.ijir.3900369.

[14] Karadeniz T, Topsakal M, Aydogmus A, Basak D. Erectile dysfunction under age 40: etiology and role of contributing factors. ScientificWorldJournal 2004;4 Suppl 1:171-4. https://doi.org/10.1100/tsw.2004.64.

[15] Roumeguère $T$, Wespes E, Carpentier Y, Hoffmann P, Schulman CC. Erectile dysfunction is associated with a high prevalence of hyperlipidemia and coronary heart disease risk. Eur Urol 2003;44:355-9. https://doi.org/10.1016/S0302-2838(03)00306-3.

[16] Kendirci M, Nowfar S, Hellstrom WJG. The impact of vascular risk factors on erectile function. Drugs of Today 2005;41:65-74. https://doi.org/10.1358/dot.2005.41.1.875779.

[17] Rogers JH, Karimi H, Kao J, Link D, Javidan J, Yamasaki DS, et al. Internal pudendal artery stenoses and erectile dysfunction: Correlation with angiographic coronary artery disease. Catheter Cardiovasc Interv 2010;76:882-7. https://doi.org/10.1002/ccd.22646.

[18] Kaiser FE, Viosca SP, Morley JE, Mooradian AD, Davis SS, Korenman SG. Impotence and Aging: Clinical and Hormonal Factors. J Am Geriatr Soc 1988;36:511-9. https://doi.org/10.1111/j.1532-5415.1988.tb04021.x.

[19] Gholami SS, Rogers R, Chang J, Ho HC, Grazziottin T, Lin CS, et al. The effect of vascular endothelial growth factor and adeno-associated virus mediated brain derived neurotrophic factor on neurogenic and vasculogenic erectile dysfunction induced by hyperlipidemia. J Urol 2003;169:1577-81. https://doi.org/10.1097/01.ju.0000055120.73261.76.

[20] Li R, Cui K, Wang T, Wang S, Li X, Qiu J, et al. Hyperlipidemia impairs erectile function in rats by causing cavernosal fibrosis. Andrologia 2017;49. https://doi.org/10.1111/and.12693.

[21] Qiu X, Fandel TM, Lin G, Huang YC, Dai YT, Lue TF, et al. Cavernous smooth muscle hyperplasia in a rat model of hyperlipidaemia- associated erectile dysfunction. BJU Int 2011;108:1866-72. https://doi.org/10.1111/j.1464-410X.2011.10162.x.

[22] Kobat MA, Firdolas F, Balin M, Çelik A, Bentli R, Baydas A. Circulating soluble lectin-like oxidized low-density lipoprotein receptor-1 levels are associated with erectile dysfunction in patients without known coronary artery disease. J Sex Med 2013;10:2782-9. https://doi.org/10.1111/j.1743-6109.2012.02964.x.

[23] Saltzman EA, Guay AT, Jacobson J. Improvement in 
erectile function in men with organic erectile dysfunction by correction of elevated cholesterol levels: a clinical observation. J Urol 2004;172:255-8. https://doi.org/10.1097/01.ju.0000132368.10458.66.

[24] Wei M, Macera CA, Davis DR, Hornung CA, Nankin HA, Blair SN. Total cholesterol and high density lipoprotein cholesterol as important predictors of erectile dysfunction. Am J Epidemiol 1994;140:930-7. https://doi.org/10.1093/oxfordjournals.aje.a117181.

[25] Corona G, Cipriani S, Rastrelli G, Sforza A, Mannucci E, Maggi M. High Triglycerides Predicts Arteriogenic Erectile Dysfunction and Major Adverse Cardiovascular Events in Subjects With Sexual Dysfunction. J Sex Med 2016;13:1347-58. https://doi.org/10.1016/j.jsxm.2016.07.004.

[26] Atahan Ö, Kayigil Ö, Hizel N, Metin A. Is apolipoprotein(a) an important indicator of vasculogenic erectile dysfunction? Int Urol Nephrol 1998;30:185-91. https://doi.org/10.1007/BF02550575.
[27] Kim SC. Hyperlipidemia and erectile dysfunction. Asian J Androl 2000;2:161-6. https://pubmed.ncbi.nlm.nih.gov/11225973/

[28] Pinnock CB, Stapleton AMF, Marshall VR. Erectile dysfunction in the community: A prevalence study. Med J Aust 1999;171:353-7. https://doi.org/10.5694/j.1326-5377.1999.tb123691.x.

[29] Corona G, Boddi V, Balercia G, Rastrelli G, De Vita G, Sforza A, et al. The effect of statin therapy on testosterone levels in subjects consulting for erectile dysfunction. J Sex Med 2010;7:1547-56. https://doi.org/10.1111/j.1743-6109.2009.01698.x.

[30] Mondul AM, Selvin E, Rohrmann S, Menke A, Feinleib M, Kanarek N, et al. Association of serum cholesterol and cholesterol-lowering drug use with serum sex steroid hormones in men in NHANES III. Cancer Causes Control 2010;21:1575-83. https://doi.org/10.1007/s10552-010-9586-6. 